\title{
Hourly rainfall distribution patterns in Java island
}

\author{
Sebastianus Priambodo ${ }^{1, *}$, Suhardjono ${ }^{1}$, Lily Montarcih ${ }^{1}$, and Ery Suhartanto ${ }^{1}$ \\ ${ }^{1}$ Department of Civil Engineering, Universitas Brawijaya, Malang, Indonesia
}

\begin{abstract}
Nowadays, water resources management development not only sees from the side of excess or lack of water in quantity, but already includes aspects of quality, health, aesthetics, comfort and environmental sustainability. The problems faced by urban areas are the disruption of activities due to flood events. The opportunities for flooding depend on climate and global weather behaviour. The magnitude of the flood depends on the rain with certain characteristic that is generally seen from the intensity and duration of rain events. While the magnitude of losses due to floods depends on the magnitude of the flood and the level of economic development of the region concerned. This paper discusses the importance of understanding the short duration of rain characteristics as well as its response to flood discharge plans in both micro and macro-depleting systems in urban areas. With this understanding, it is expected that handling actions at various levels of the disaster cycle can be well anticipated so that the negative impacts that may arise can be minimized. Characteristic analysis of short duration rainfall is done by looking at the pattern of hourly rainfall distribution occurring in several rainfall observation stations in Java Island. The Mononobe equation is used to see the level of compatibility of the rainfall distribution pattern with RMSE, NMSE and MAE score indicators. The analysis results show the reliability level of Mononobe equation for the hydrology analysis in the location which has no short duration rainfall data.
\end{abstract}

\section{Introduction}

Rainfall is a primary input in hydrological and environmental planning. When rainfall falls on the earth surface as a hydrological cycle, various hydrological possibilities will occur due to many uncertainties. Design rainfall input can be either rainfall depth at a location or a hyetograph. In urban drainage planning, storm design is calculated from depth rainfall using the Rational method. Meanwhile, hyetograph is needed for flood control design.

Rainfall has own characteristics, such as intensity, duration, depth, frequency, the area of distribution. Tadashi Tanimoto researched hourly rainfall pattern in Java, Indonesia and established 8 hour rainfall distributions [1]. Aldrian and Susanto [2] conducted characteristic research on rainfall pattern in Indonesia using monthly data from 1961-1993. Based on the existing rainfall pattern types. Indonesia is divided into 3 rainfall patterns

*Corresponding author: sebastianus.priambodo@yahoo,com 
namely: Monsoonal Type (A), Equatorial Type (B) and Local Type (C). Monthly rainfall distribution patterns for type A areas occurred in November-March, for type B occurring 2 times between March-May and October-November, and for type, C occurred in June-July. This situation caused by the geographic archipelago of Indonesia lays between two continents and two oceans, crossed by the equator. The areas of each rainfall pattern are shown in Fig. 1.

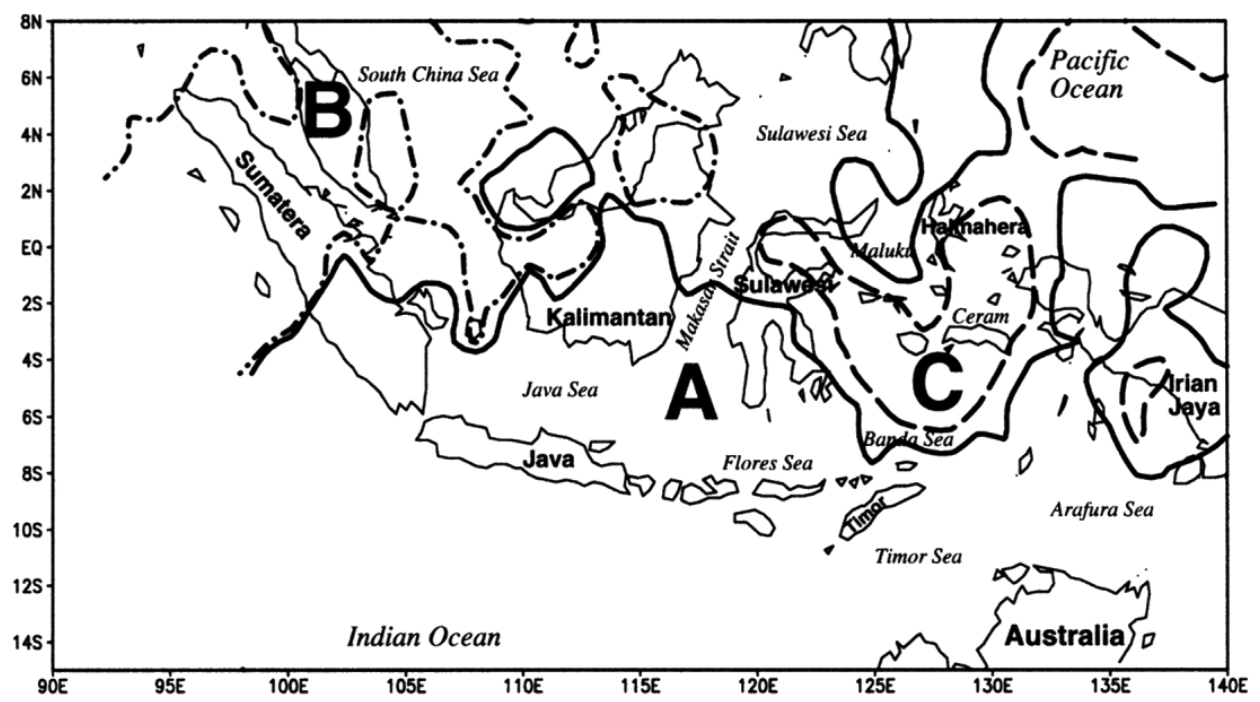

Fig. 1. The area of each type rainfall distribution pattern in Indonesia.

Rainfall intensity is one of the characteristics which can be classified geographically. Varikoden, et al. [3] defined rainfall intensity in Malaysia's peninsula in categories as: light I $<4 \mathrm{~mm} /$ hour; moderate $4<\mathrm{I}<8 \mathrm{~mm} /$ hour; heavy $8<\mathrm{I}<12 \mathrm{~mm} /$ hour and very high I $>$ $12 \mathrm{~mm} /$ hour. Fragoso and Tilde [4] defined heavy intensity, such that its magnitude exceeds $40 \mathrm{~mm} /$ day in South Portugal. Chen et al. [5] defined heavy intensity occur at 50 $\mathrm{mm} /$ day in Taiwan. Houze et al. [6] define heavy intensity when an event occurs in an area $>12,500 \mathrm{~km}^{2}$ with $\mathrm{I}>25 \mathrm{~mm}$ for 25 hours.

Understanding rainfall characteristics variability in Indonesia and surrounding areas is essential for hydrological and environmental planning. The rainfall pattern could be diverse in each region. Furthermore, on the selection of hyetograph on the location without rainfall gauges for discharge design analysis can minimize the resulting error.

\section{Data and methodology}

Research location for hourly rainfall distribution patterns was conducted for Java Island. The island is classified as monsoonal type. In this research, data taken from 8 rainfall station are used (Table 1). The stages of research activities can be shown in Fig. 2.

\section{Literature review}

\subsection{Rainfall distribution (RD)}

Rainfall distribution is a function of time that describes the information of the variation of rainfall depth during a rainfall event. Rainfall distribution can be described in a discrete or 
continuous form. The discrete rainfall distribution is illustrated in a high rainfall histogram or rainfall intensity as ordinate and time as abscissa. While the continuous form describes the relationship of cumulative rainfall rate as a function of time.

Table 1. Rainfall stations data in Java Island.

\begin{tabular}{|c|c|c|c|}
\hline Rainfall station & Province & El. (m.a.s.l.) & $\begin{array}{l}\text { Observed record } \\
\text { period }\end{array}$ \\
\hline Angin-angin & DI Yogyakarta & 320 & $2010-2016$ \\
\hline Kemayoran & DKI Jakarta & 5 & $2000-2016$ \\
\hline Pondok Betung & DKI Jakarta & 30 & $2000-2017$ \\
\hline Bogor & West Java & 220 & $\begin{array}{c}2000-2008 \& \\
2010-2017\end{array}$ \\
\hline Citeko & West Java & 900 & $\begin{array}{c}1996-2001 \& \\
2004-2014\end{array}$ \\
\hline Semarang & Central Java & 3 & $\begin{array}{c}2001-2006 \& \\
2015-2017\end{array}$ \\
\hline Karang Ploso & East Java & 600 & $2007-2016$ \\
\hline Perak & East Java & 3 & $2015-2017$ \\
\hline
\end{tabular}

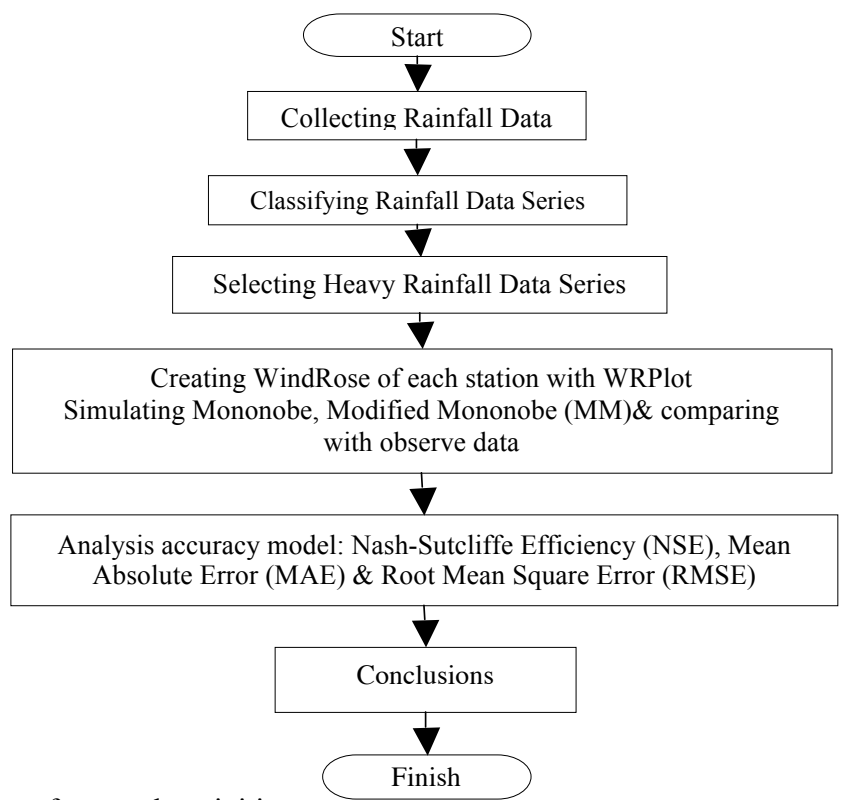

Fig. 2. Flow chart of research activities.

On the calculation of the design storm, one of the inputs is a hyetograph. Commonly, hyetographs are created by an automatic hourly rainfall recorded data. It should be realized that not every location in Indonesia has an automatic rainfall gauge. Synthetic rainfall distribution model must be used, such as uniform/constantly intensity, triangle, bell shape or alternating block method [1]. 


\subsection{Rainfall and topography}

Both physical and dynamic processes in the atmosphere are influenced rainfall intensity and rainfall period. Meanwhile, one of the factors that affect the physical and dynamic atmosphere is topography itself [7].

There is three main process which correlates rainfall and topography: 1) The adiabatic process, which as a result of obstructions such as buildings and mountains. These natural and artificial obstructions will hold the air mass is moving horizontally, then force upward; 2) The horizontal convergence process, which results from a pressure difference on the surface, causes the air mass to rise and then rises upward with lower air temperature; and 3) The convective process, where warming emitted by the surface of the earth, both from land and sea will warm the air mass and then rise to a low-temperature place [2].

\subsection{Rainfall characteristics}

Characteristics of short duration rainfall analysis using wind roses analogy, rainfall duration, and rainfall depth can also be described in this way, where the wind direction is replaced with rainfall duration, while wind speed can be replaced with the rainfall depth. Through WRPLOT software, the frequency of distribution for each rainfall duration will be known including the duration of dominant rainfall and the frequency of rainfall depth [8].

\subsection{Mononobe equations}

On early 1976, Mononobe equations [7] was introduced in Indonesia and become familiar with hydrology design for calculating rainfall intensity at any time. The primary input is maximum diurnal rainfall data. The form of the equation is as follow.

$$
I=\frac{R_{24}}{24}\left(\frac{24}{t}\right)^{\frac{2}{3}}
$$

where $I=$ rainfall intensity during $\mathrm{t}$ - hour ( $\mathrm{mm} /$ hour), $t=$ time of rainfall or time travel (hour), $R_{24}=$ maximum diurnal rainfall data $(\mathrm{mm})$.

Winda [9], researched rainfall distribution pattern using mononobe equation which has been modified. Mononobe equation was modified by replacing numerator and denominator 24 hour with $t$ (rainfall duration). The equation of Modified Mononobe (MM) is:

$$
I=\frac{R_{24}}{24}\left(\frac{T}{t_{32}}\right)^{\frac{2}{3}}
$$

Constanta of 2/3 in Mononobe equation is still used. For transforming rainfall intensity into depth rainfall, this equation below should be used.

$$
R_{T}=t_{t} I_{t}-t_{(t-1)} I_{(t-1)}
$$

where $I=$ rainfall intensity during $\mathrm{t}$ - hour ( $\mathrm{mm} /$ hour), $I_{t}=$ rainfall intensity at t-time $\left(\mathrm{mm} /\right.$ hour), $T=$ rainfall duration (hour), $t_{n}=$ rainfall duration in sequence (hour), $t_{t}=$ rainfall duration at t-time (hour), $R_{24}=$ maximum diurnal rainfall data $(\mathrm{mm})$. 


\section{Results and discussion}

In this research, heavy rainfall is presented by the magnitude of hourly maximum rainfall events. The significant maximum rainfall is heavy rainfall, I $>10 \mathrm{~mm} / \mathrm{hour}$ or $50 \mathrm{~mm} /$ day [7]. Kemayoran station is chosen among others for hourly rainfall distribution represent.

The characteristic heavy rainfall in Kemayoran Station is shown in Fig. 3. The percentages of heavy rainfall events are drawn by histograms. Meanwhile, the Wind Rose (WR) plot is used to present the number of the rainfall event, which are divided by their intensity and duration. It's shown at WR plot that long duration rainfall events rarely occur. Mostly the heavy-rainfall event occurs in short duration rainfall, which is in duration 1 up to 4 hours and a range of $40-60 \mathrm{~mm} /$ hour intensity (Table 2). From the rainfall characteristics analysis conducted to all station, only Citeko and Bogor Station, which has a few evidence of long duration rainfall which has a duration up to more than 20 hours.
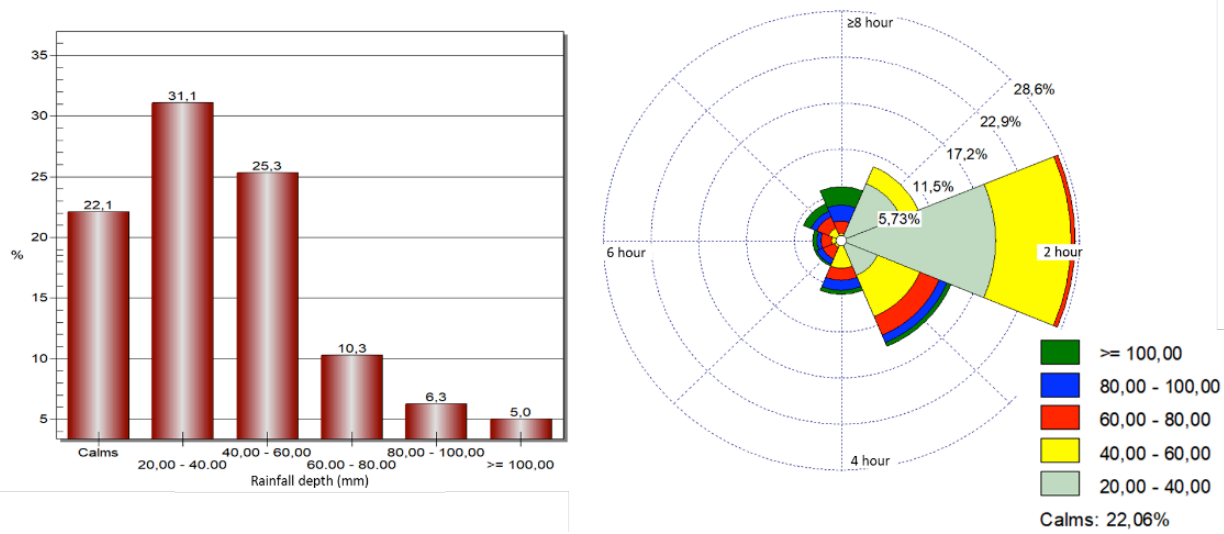

Fig. 3. Rainfall characteristics at Kemayoran Station.

Table 2. Classification of heavy rainfall at Kemayoran Station.

\begin{tabular}{|l|l|c|c|c|c|c|l|}
\hline \multicolumn{2}{|c|}{ Rainfall depth (mm) } & $\mathbf{2 0 - 4 0}$ & $\mathbf{4 0 - 6 0}$ & $\mathbf{6 0 - 8 0}$ & $\mathbf{8 0 - 1 0 0}$ & $>\mathbf{= 1 0 0}$ & Total \\
\hline 1 & Duration 8 hour & 0 & 4 & 6 & 8 & 9 & 27 \\
\hline 2 & Duration 1 hour & 31 & 9 & 0 & 0 & 0 & 40 \\
\hline 3 & Duration 2 hour & 74 & 36 & 2 & 0 & 0 & 112 \\
\hline 4 & Duration 3 hour & 19 & 22 & 10 & 4 & 2 & 57 \\
\hline 5 & Duration 4 hour & 0 & 14 & 6 & 5 & 2 & 27 \\
\hline 6 & Duration 5 hour & 0 & 4 & 6 & 3 & 1 & 14 \\
\hline 7 & Duration 6 hour & 0 & 5 & 5 & 2 & 2 & 14 \\
\hline 8 & Duration 7 hour & 0 & 7 & 6 & 3 & 4 & 20 \\
\hline & Sub-Total & 124 & 101 & 41 & 25 & 20 & 311 \\
\hline & Calms & & & & & & 88 \\
\hline & Total & & & & & & 399 \\
\hline
\end{tabular}


On the remote area which has no short duration rainfall data, synthetic hyetograph is used to transform diurnal rainfall data into hyetograph. The perform of hyetograph made by Mononobe and MM equations is drawn in Fig. 4. It can be noticed that the pattern was slightly different from the observed data. Those equations trigger hyetograph start with higher rainfall depth. Meanwhile, the observed data start with lower rainfall depth. Furthermore, accumulation of rainfall depth between observed data and MM equations is equal, but it doesn't work in Mononobe equation. At this point forward, the MM equation is chosen for model test accuracy. The diversity of rainfall distribution patterns is evidenced, by the influence of topography and location.

Table 3. Model test accuracy of Modified Mononobe.

\begin{tabular}{|c|c|c|c|c|c|c|c|c|c|}
\hline & & $\begin{array}{c}1^{\text {st }} \\
\text { hour }\end{array}$ & $\begin{array}{c}2^{\text {nd }} \\
\text { hour }\end{array}$ & $\begin{array}{c}3^{\text {th }} \\
\text { hour }\end{array}$ & $\begin{array}{c}4^{\text {th }} \\
\text { hour }\end{array}$ & $\begin{array}{c}5^{\text {th }} \\
\text { hour }\end{array}$ & $\begin{array}{c}6^{\text {th }} \\
\text { hour }\end{array}$ & $\begin{array}{c}7^{\text {th }} \\
\text { hour }\end{array}$ & $\begin{array}{c}8^{\text {th }} \\
\text { hour }\end{array}$ \\
\hline \multirow{3}{*}{$\begin{array}{c}\text { duration } \\
2 \text { hour }\end{array}$} & NSE & 0.14 & 0.14 & & & & & & \\
\hline & MAE & 5.06 & 5.06 & & & & & & \\
\hline & RMSE & 1.28 & 1.28 & & & & & & \\
\hline \multirow{3}{*}{$\begin{array}{l}\text { duration } \\
3 \text { hour }\end{array}$} & NSE & -0.66 & -0.66 & -0.66 & & & & & \\
\hline & MAE & 17.53 & 17.53 & 17.53 & & & & & \\
\hline & RMSE & 2.97 & 2.97 & 2.97 & & & & & \\
\hline \multirow{3}{*}{$\begin{array}{c}\text { duration } \\
4 \text { hour }\end{array}$} & NSE & -0.48 & -0.48 & -0.48 & -0.48 & & & & \\
\hline & MAE & 24.74 & 24.74 & 24.74 & 24.74 & & & & \\
\hline & RMSE & 5.49 & 5.49 & 5.49 & 5.49 & & & & \\
\hline \multirow{3}{*}{$\begin{array}{c}\text { duration } \\
5 \text { hour }\end{array}$} & NSE & -0.03 & -0.03 & -0.03 & -0.03 & -0.03 & & & \\
\hline & MAE & 24.83 & 24.83 & 24.83 & 24.83 & 24.83 & & & \\
\hline & RMSE & 7.63 & 7.63 & 7.63 & 7.63 & 7.63 & & & \\
\hline \multirow{3}{*}{$\begin{array}{c}\text { duration } \\
6 \text { hour }\end{array}$} & NSE & -5.54 & -5.54 & -5.54 & -5.54 & -5.54 & -5.54 & & \\
\hline & MAE & 30.58 & 30.58 & 30.58 & 30.58 & 30.58 & 30.58 & & \\
\hline & RMSE & 9.62 & 9.62 & 9.62 & 9.62 & 9.62 & 9.62 & & \\
\hline \multirow{3}{*}{$\begin{array}{l}\text { duration } \\
7 \text { hour }\end{array}$} & NSE & -6.04 & -6.04 & -6.04 & -6.04 & -6.04 & -6.04 & -6.04 & \\
\hline & MAE & 28.05 & 28.05 & 28.05 & 28.05 & 28.05 & 28.05 & 28.05 & \\
\hline & RMSE & 7.16 & 7.16 & 7.16 & 7.16 & 7.16 & 7.16 & 7.16 & \\
\hline \multirow{3}{*}{$\begin{array}{l}\text { duration } \\
8 \text { hour }\end{array}$} & NSE & -8.97 & -8.97 & -8.97 & -8.97 & -8.97 & -8.97 & -8.97 & -8.97 \\
\hline & MAE & 31.51 & 31.51 & 31.51 & 31.51 & 31.51 & 31.51 & 31.51 & 31.51 \\
\hline & RMSE & 12.50 & 12.50 & 12.50 & 12.50 & 12.50 & 12.50 & 12.50 & 12.50 \\
\hline
\end{tabular}




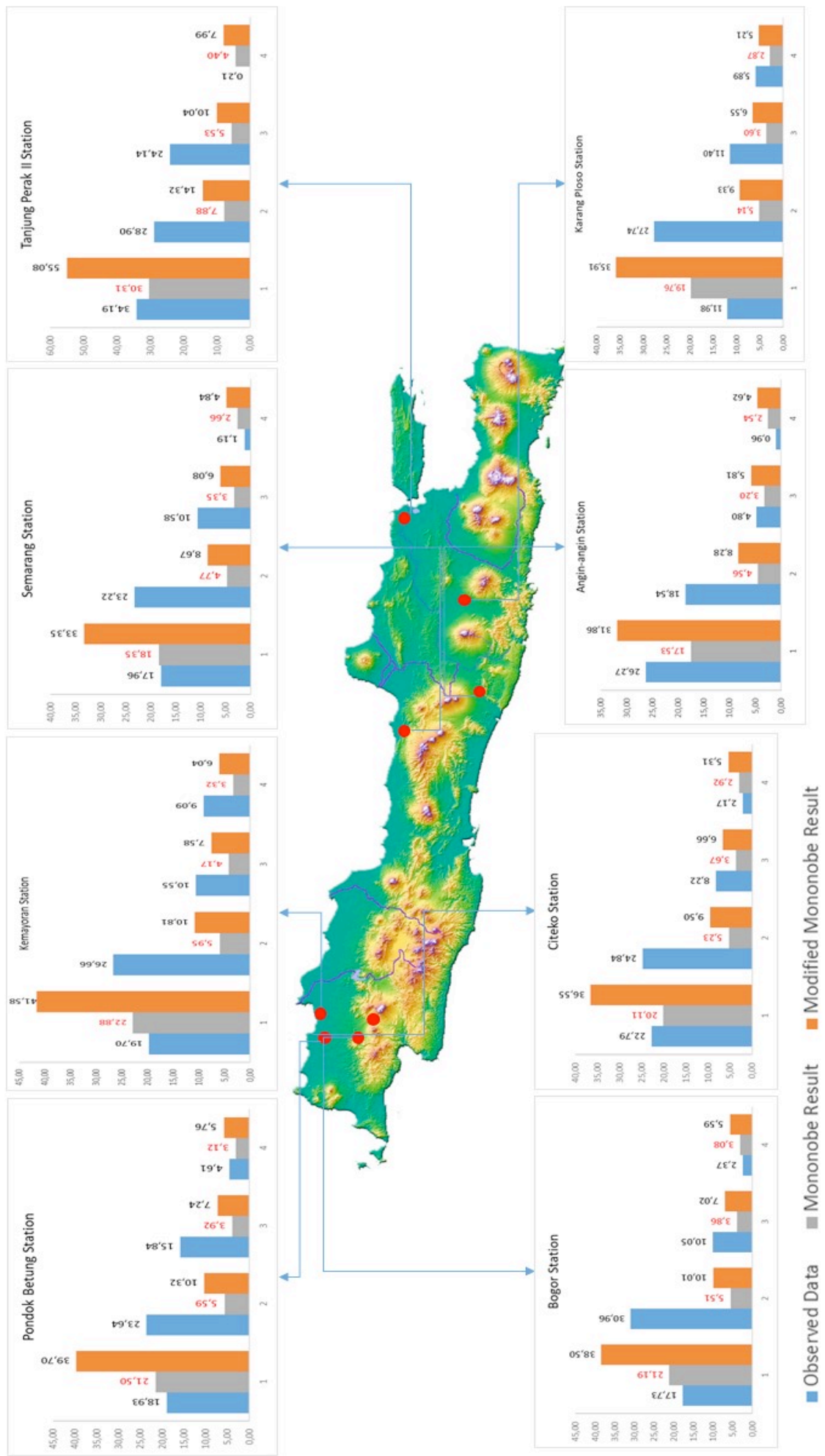

Fig. 4 . Rainfall distribution pattern of duration 4 hour over Java. 
The hourly rainfall pattern in Karang Ploso, Citeko, Bogor, Pondok Betung, Jakarta and Semarang shows the same pattern, neither in Yogyakarta and Surabaya (Fig. 4). The hyetograph shapes are shown climb up at the beginning and slightly down at third hour. At Yogyakarta and Surabaya, the hyetograph shape shows a higher magnitude and then gradually diminishes. From the elevation among Yogyakarta and Surabaya, Yogyakarta located higher than Surabaya, the percentage of rainfall distribution is higher in the beginning. Those hyetographs for short duration rainfall on each location can be used for input in hydrological and environmental planning.

The result of Nash-Sutcliffe Efficiency (NSE), Mean Absolute Error (MAE) and Root Mean Square Error (RMSE) are shown in Table 3. The optimal value of NSE is 1 and should be more than 0 to show that the accuracy can be acceptable concerning the mean value of the data. The optimal value of RMSE should be closed to 0 to show that the accuracy able to accept it. Based on the optimal value of NSE and RMSE, the result of the $\mathrm{MM}$ equation on rainfall distribution still needs calibration.

\section{Conclusions}

This research extends understanding of rainfall distribution pattern over Java Island. Most rainfall occurred over Java as short duration rainfall. Durations are between 1 to 4 hours. With data from 8 stations, the hyetograph over Java is still not enough to display fluctuations due to topography and geographical location. To improve this research, more hourly rainfall data is required. Further investigation could examine more rainfall distribution pattern equations to approach the real condition of Java Island.

Acknowledgments were conveyed to Balai Besar Wilayah Sungai Opak Oyo, Mbak Indah and Dimas who has helped provide data of hourly rainfall data.

\section{References}

1. B. Triatmojo, Hidrologi terapan (Beta Offset, Yogyakarta, 2016)

2. E. Aldrian, R. D. Susanto, Int. J. of Climatology 23, (2003)

3. H. Varikoden, B. Preethi, A. A. Samah, C. A. Babu, J. of Hydrology 404, 1-2 (2011)

4. M. Fragoso, P.T. Gomes, Int. J. of Climatology 28, 4 (2008)

5. C.-S. Chen, Y.-L. Chen, C.-L. Liu, P.-L. Lin, W.-C. Chen. Weather and Forecasting 22, 5 (2007)

6. R.A. Jr. Houze, K.L. Rasmussen, S. Medina, S.R. Brodzik, U. Romatschke. Bull. Amer. Meteor. Soc. 92 (2011)

7. S. Sosrodarsono, K. Takeda, Hidrologi untuk pengairan (Pradnya Paramita, Jakarta, 1976)

8. L. Environmental, Available at: https://www.weblakes.com/products/wrplot/ index.html (2018)

9. Winda, Pola distribusi hujan jam-jaman di sub DAS Keduang (Universitas Sebelas Maret, Surakarta, 2013) 